\title{
A Systematic Approach To Enhance Implementation Of Energy Management Systems At Leading Oil Companies
}

\author{
Hashim K.M. ${ }^{1,2}$, Hassim Mimi H. ${ }^{1}$, Ng D.K.S. ${ }^{3}$ \\ ${ }^{1}$ School of Chemical and Energy Engineering / Centre of Hydrogen Energy, University Teknologi Malaysia, 81310 \\ UTM Johor Bahru, Malaysia \\ ${ }^{2}$ Saudi Arabian Company Dhahran 31311, Kingdom of Saudi Arabia \\ ${ }^{3}$ School of Engineering and Physical Sciences, Heriot-Watt University, No. 1, Jalan Venna P5/2, Precinct 5, 62200 \\ Putrajaya Malaysia
}

*Corresponding author:mimi@ cheme.utm.my

\author{
Article History \\ Received: March 16, 2020 \\ Received in revised form: June 01, 2020 \\ Accepted: June 12, 2020 \\ Published Online: June 30, 2020
}

\begin{abstract}
Conserving energy becomes part of business culture, and it describes by reducing energy consumption to achieve the same works. Due to increasing internal demand on energy in many parts of the world, it has pushed societal expectations to oil companies toward rigorously conserveenergy and ex plores ways to enhance its energy performance. As globalenergy demand soars, it is known that the industries, power plants and tran sportation sectors are the main contributors to the intensive ut ilization of energy resources. The demand from the growing population has overwhelmed current capacity. It is inevitable, therefore, many oil companies are now participating in on-going efforts to conserve energy, and do so in a susta inable manner by means of implementing energy management systems (EnMS) in accordance to internationally recognized standards. However, its progress ha s just been seen and unfortunately, most of oil companies are far away from a matured management to excel in energy performance. It appears that many of oil companies consider EnMS as an ambition rather than a platform to excel in energy performance. In fact, cost reduction is a main focus instead of exploring other hidden benefits of EnMS. More seriously, lack of dedicated steps to push for the successful implementation. This paper discusses a systematic approach that drive for full implementation of EnMS at one of the lea ding oil companies.
\end{abstract}

Keywords: Energy Management Systems; Deployment and implementation approaches; Energy improvement program; Energy improvement measures

\subsection{INTRODUCTION}

In current scenario, oil industry will remain essential to global economic and prosperity for decade to come [1]. World Bank indicatesthat fossil fuel is still a major source of the world power generation as the demand will grow at the a verage of $3.6 \%$ to $4.0 \%$ peryear towards year 2035 [1]. Focus on energy performance improvement has becoming one of the top globaldiscussion subjects due to the factsof hiked in fossil fuel price, changed in living standards, increased in Green House Gas (GHG) awareness as well as fair business practices in related to subsidies and environment regulations [1]. A systematic energy resources management will sustain the glory of oil companies and oil producing countries, and keepoil and gas sectors moving [2]. Past history and future forecasts illustrate the rapid increase in energy demand globally. Key contributors to the intensive utilization of natural resources are coming from consumable products manufacturing sectors , power generation and transportation sectors. This, a ga in, is a n outcome of growing population and improving living conditions [3].

Many oil companies have started focusing in energy efficiency to meet societal expectations for thoroughly explore ways to sa ve energy. Government has imposed stringent requirements on environmental impact, equipment specifications, and other social obligations. In current industrial practice, a n energy management systems (EnMS) is becoming one of typical initiatives that have been evolving since the late 1990s. According to the International Petroleum Industry Environmental Conservation Association (IPIECA), EnMS is a preferred management programs to assist oil companies in excelling its energy utilizations 
[4]. The first revision of EnMS was released by International Organization for Standardization (ISO) in June 2011, and was revised in 2018. EnMS engages oil companies to follow a systematic approach in managing energy resources, by means of energy efficiency applications, energy supply security, energy use and consumption reviews, performance measures, as well as continuous im provement efforts [5].

Each concerned oil company can decide the need for tra nsition in adopting new challenging rea lities, vibrant business m odek or to continue leveraging innovative technologies. Despite the increase in energy demand and societal expectations for effectiveness in EnMS implementation, it appears that EnMS is just a certificate on the wall for many oil companies [6]. In a survey conducted in April 2015 by DNV GL - Business Assurance customer on 1557 professionals from the primary, secondary and tertiary sectors of global companies on approach toward EnMS. The survey showed that $57 \%$ of the companies had an established EnMS or any similar program in place [6]. But progress had just started, and the concerned companies had yet to fully benefits from EnMS implementation, a s energy efficiency concepts had not been effectively implemented.

Most oil companiesbelieve EnMS as a slogan, rather than a condition applying to companies in running their businesses. Indeed, the main focus is to reduce cost rather than to drivefor excellencein energy performance [7]. The priority is a lways on financial impact rather than effort, to improve the use of energy resources [8]. In contrast, firming commitments from various levels within a company' entities, establishing the right strategies, planning, executing agreed action items, and monitoring and re vising stra tegies as necessary have yet to be embraced in a larger scope [9]. The full implementation of EnMS can be a major contributor to a ddress those challenges [10]. Again, another survey was conducted by the Metrus Group, Inc. [11] on ra ndomly selected 122 multinational companies, to understand the relationship between energy performance to visions and strategies. Outcomes from the survey indicated that a successful company with clear vision and strategy planning tends to benefit the most. It is a valid sta tement as a successfulEnMS implementation requires a strong vision statement and dedicated execution strategies, followed by actual field implementation [5].

It appears that having established a deployment strategy is one of crucial initial steps to impel for sustainable EnMS implementation. Successful implementation of EnMS is a challenging milestone that requires the highest level of commitments from respective personnel within the company. For example, there are two identified initiatives to push for successful energy efficiency in the Gulf Cooperation Council (GCC). Adopting energy efficiency milestones introduced by League of Arab States and implementing right energy management practices were two of them. It has yet to be successful to change the trends [12]. Identified obstacles in a rea of concerns in achieving EnMS vision are listed in Table 1. These challenges were captured from a survey conducted on 22 members of the Ara bLeague in 2013.

Table 1 Challenges to achieve EnMS vision [12]

\begin{tabular}{|l|l|}
\hline \multicolumn{1}{|c|}{ Area of Concerned } & \multicolumn{1}{|c|}{ Potential Obstacles } \\
\hline Technical knowhow & $\begin{array}{l}\text { Most concerned oil companies are unaware of how to effectively conserve energy. Lack of } \\
\text { knowledge in optimizing the common major energy users, e.g., furnaces and boilers operations, } \\
\text { pump load management, water and many other industrial and non-industrial equipment. }\end{array}$ \\
\hline Incentives & $\begin{array}{l}\text { It appears that a current energy subsidy in the GCC provides little incentive to adopt energy } \\
\text { efficiency and conservation measures. Similarly, due to low energy prices, savings from energy } \\
\text { improvement efforts will not be significant enough to be justified under capital expenditure } \\
\text { (CAPEX) for profit improvement (PI) category. }\end{array}$ \\
\hline Mind-share & $\begin{array}{l}\text { Energy efficiency has not been in the top agenda of oil companies. Many of them have yet to } \\
\text { identify energy as a significant operating expenditure (OPEX) }\end{array}$ \\
\hline $\begin{array}{l}\text { Geo-political structure of the } \\
\text { region }\end{array}$ & $\begin{array}{l}\text { Most oil companies owned organizations/facilities are scattered across large areas, making it } \\
\text { difficult to coordinate regional energy efficiency and conservation programs. }\end{array}$ \\
\hline
\end{tabular}

Achieving the desired outcomes of EnMS is a challenge that requires the highest level of planning, commitments, and a strong push by top management [13]. Many hidden benefits and potential losses can be discovered by fully subscribing the right reference for EnMS. The main content of the proposed strategies include simplified EnMS steps, and a deployment starter kit that can drastically im prove the implementation pace of EnMS.

The paper presents strategies that can induce ra pid deployment and implementatio nof an EnMS at any interested oil company. The proposed strategies a re based on successful implementation at several oil companies. Its application is driven by needs of the oil companies in fully deploying the EnMS, in which the main objectives are to op timize energy usages, reduce GHG footprint and OPEX, and remain competitive in the global arena [14]. Major phasesrelated to the implementation strategies will be discussed in the next sections. Several examples, case studies, and best practices will be presented to prove the nature of EnMS a pplications, and the progress made to mitiga te any probable obstacle. 


\subsection{METHODOLOGY}

The proposed EnMS implementation strategies shall drive to meet full requirements of the recognized international standard of Energy Management Systems (ISO50001.2018), and other specific requirements mandated by concerned oil companies. Subsequently, it should be simple to ex pedite for sustainable implementation of EnMS within an a cceptable time frame. Worrel [2] indicates that ISO 50001 is one of most popular energy management references within oil companies as it furnishes the wellestablished best practices to drive smooth deployment of the programs.

Figure 1 illustrates major steps to be taken prior to accomplish the study objective. Starting with a clear define objective and engagement from top management are key success of the study. It follows by collecting information, conducting surveys and reviewing a pplicable references e.g., industries best-practices, case studies, books, journal and related articles. Subsequently, any applicable information will be used to determine the most effective approaches and initiatives to enhance EnMS implementation. The next stage is to conduct comprehensive a nalysis of successful best practice s and strategies applied by several lea ding oil com panies. Finally, a case study for the successful implementation of the said strategies at one of leading oil companies, located in Middle East will be included in the paper.

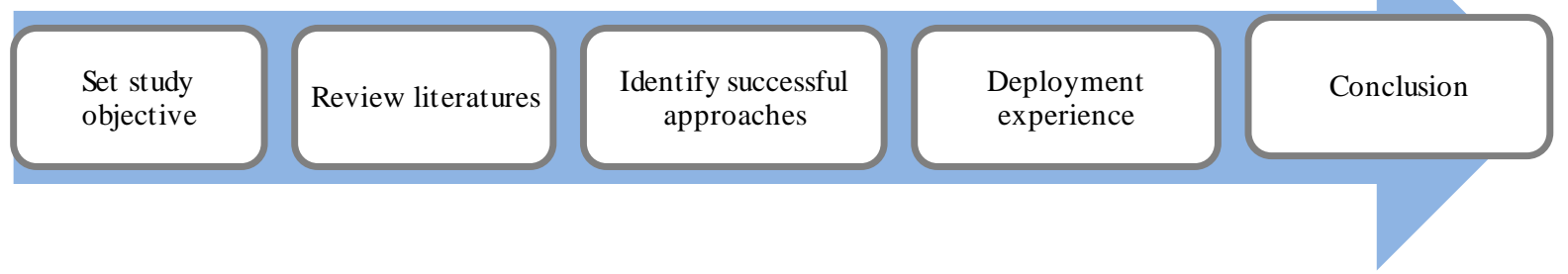

Figure 1 Study steps

\subsection{RESULTS AND DISCUSSION}

The following sub-titles will describe the detailed mechanisms, to define suitable strategies to enhance EnMS implementation at the concerned oil com panies. Several sustainable measures embed to enhance deployment and drive for full im plementation of EnMS at concerned organizations. It follows with a case study a tone of the lea ding oil companies.

\subsection{Understand Challenges In Deploying EnMS}

There are ma ny common factors that affect the slow progress of EnMS implementation a mong oil companies [15]. According to the surveys conducted on 30 oil companies in Middle East, several major challen ges in implementing EnMS were ca ptured and summarized. Subsequently, identified realistic mitiga tions were collected to address thosechallenges and will be discussed in details in the next section. The findings ba sed on the summarized challenges that prevent oil companies from achieving the full benefits of deploying and implementing the EnMS are listed in the first column of Table 2.

Table 2 List of typical EnMS implementation challenges and proposed strategies

\begin{tabular}{|c|c|}
\hline Challenges & Identified implementation strategy \\
\hline Set clear corporate direction & $\begin{array}{l}\text { - Identify tangible and intangible benefits by implementing EnMS. } \\
\text { - Indicate clear link to respective business goals. } \\
\text { - Fulfill energy policy expectations. } \\
\text { - Gather commitment from management through regular updates. }\end{array}$ \\
\hline $\begin{array}{l}\text { Gain commitments from: } \\
\text { a. Top management. } \\
\text { b. Energy coordinator } \\
\text { c. All critical positions } \\
\text { d. Employees and contractors }\end{array}$ & $\begin{array}{l}\text { - Introduce e-learning courses to senior and middle management. } \\
\text { - Include roles and responsibilities of management, energy coordinator and its energy team in } \\
\text { EnMS reference document. } \\
\text { - Provide relevant awareness events such as e-learning courses, workshops, technical exchanges } \\
\text { meetings, forums and conferences. }\end{array}$ \\
\hline Solve conflicting priority. & $\begin{array}{l}\text { - Appointment letters for energy related personal } \\
\text { - Include in individual performance goal for each member of energy team. }\end{array}$ \\
\hline Enhance competency. & $\begin{array}{l}\text { - Develop list of recommended courses. } \\
\text { - Include detailed qualification of critical EnMS positions in the framework. }\end{array}$ \\
\hline
\end{tabular}




\begin{tabular}{|c|c|}
\hline $\begin{array}{l}\text { Energy data analysis, monitoring, } \\
\text { corrective and preventive. }\end{array}$ & $\begin{array}{l}\text { - Specify energy performance indicators (EnPIs). } \\
\text { - Establish data collection mechanism. } \\
\text { - Simplify operating manuals. }\end{array}$ \\
\hline High cost of implementing EnMS & Embed into existing companywide management programs. \\
\hline Obtain full Implementation & $\begin{array}{l}\text { - Gain momentum with other matured programs implemented by companies. } \\
\text { - Introduce self-evaluation assessment. }\end{array}$ \\
\hline $\begin{array}{l}\text { Increase pressure from society i.e. new } \\
\text { product and legal requirements. }\end{array}$ & $\begin{array}{l}\text { - Adopt the right EnMS reputable standards, which: } \\
\text { - Proven to lead for energy performance improvement. } \\
\text { - Simplicity to users. } \\
\text { - Consistence with other management programs such as environment management systems } \\
\text { (EMS), safety management systems (SMS), total productive maintenance (TPM) and other } \\
\text { matured programs. } \\
\text { - Establish lessons learned and best practices. }\end{array}$ \\
\hline
\end{tabular}

The surveys outline major challenges, e.g., clear corporate direction, commitments from employees and respective contractors, completing priority of energy critical persons, competency and a wareness enhancement, and several others factors. Most of respondents were aware of the need to push for EnMS implementation in concerned oil companies. In addition, some respondents' feedback indicated that EnMS was not in the priority list or considered as one of business goals by their compan ies, which were focusing in meeting production targets, reliability as well as health, safety, and environment (HSE). In fact, several of these companies were ISO 50001 certified and received regional and international recognition for excellent performancein energy related subjects. They were lacking in planning to successfully implement the full scope of EnMS. Without dedicated focus, it makes implementation failure inevitable. Similarly, a lack of strong implementation strategies and clear vision will jeopardize the intention of EnMS and its benefits.

\subsection{Identify Strategies To Gain Full Benefits of EnMS}

Outcomes from the survey (Section 3.1) identifies that one of critical a pproaches or strategies to gain full implementation of EnMS is to establish a clearly link to one of more company' business goals. Benefits of deploying EnMS and how it can contribute in achieving related business goals should be explored and shared to respective entities. Business goals may vary among oil companies. The most common ones are to improve productivity by lowering operating costs and reducing environmental impacts [10]. Several other benefits for a dopting systematic EnMS follow [4]:

- Identifying problems and opportunities for improvement proactively.

- Gaining globally recognized international standards for utilizing and managing energy resources.

- Achieving a pplicable business goals through well-structured EnMS.

- Specifying accountabilities and responsibilities in managing energy resources.

- Standardizing a nd enhancing major energy related work processes across the company functions.

- Enhancing a sset integrity a nd reliability techniques and processes.

- Mandating decision-making processes from sy stem design.

- Assisting in compliance with current a nd future voluntary and/or mandatory energy efficiency targets.

- Improving corporate image and credibility a mong customers, clients and stak eholders.

- Increasing energy a wareness among staff members and contractors.

A successful EnMS implementation requires systematic strategies. Depending on companies' specific initiatives, the proposed mitigation strategies have been identified based on respondents feedbacks as well as best practices captured from literatures. Identified implementation strategies are listed in column 2 of the Table 2 and summarized a ser following:

- Establish company' steering committee to oversee theEnMS implementation.

- Obta in fullengagement from organization.

- Subscribe to reputable and la test standards.

- Ensure the EnMS impels for energy savings. 
- Embed EnMS into existing and matured management programs.

- Introduce a comprehensiveframework template.

- Provide energy improvement guidelines template.

- Define performancemonitoring campaigns.

All proposed strategies will be described in detailed in Section 3.2.1 until Section 3.2.7.

\subsubsection{Formation of EnMS Steering Committee}

Each oil company shall establish a comprehensive Corporate Energy Management Steering Committee (EMSC) to establish a rea listic corporate energy policy and to govern its implementation corporate wide. The EMSC, which shall led by the corporate executive level and it consists of critical highest management positions representing critical organizations from operating, engineering, technology, project, fin ance a nd planning sectors. The EMSC shall meet regula rly to monitor, tra ck and guide the implementation of EnMS within multifunction's organizations. Major a ctivities shall be taken are described in Section 3.2.1.1 to Section 3.2.1.6.

\subsubsection{Top Management Commitment}

The corporate management commitment is essential to ensure adequate implementation of EnMS in all levels of the organization. The top management commitment can be seen in many forms. Firstly, EMSC is systematically lea ding the company to a chieve the corporate energy policy's goals. Secondly, EnMS requires each applicable organization to establish site energy policy which must be a ligned with the corporate policy. Additionally, the orga nizations' top managements are required to appoint the energy coordinator and energy team. The energy coordinators directly report to the top management to ensure better authorities and responsibilities [5]. Thirdly, regular management review meeting is required to ensure the implementation on the right track.

\subsubsection{Data Processing And Validation}

All applicable orga nizations are required to report the EnMS status and performance to the corporate executive management through EMSC in quarterly basis. The data goes through several review and validation processes starting from organizations' energy coordinators and its top managements, regional level, and engineering entity as an end user. All submitted energy data consolidated, a nalyzed, reported and presented to the EMSC, then to the executive management. For ea ch review and approval level, corrective actions are taken to sustain the continuous improvement.

\subsubsection{EnPIs monitoring and online solution}

The key measurement of the organizations' energy performance is corporate EnPI. The corporate EnPI is calculated from the bottom to the top levels and corporate. Thus, the corporate improvement is ma inly based on the facilities efforts. In many oil companies, corporate EnPI is defined as the ratio between energy consumption (in GJ and total production in barrels of oil equivalent (GJ/BOE). The online corporate EnPI tracks and monitors again st the targets in real-time. In case of offset, corrective action must be taken within reasonable tim eframe. Oil companies utilize the solution to a nalyze theenergy consumption of their operating facilities. Therefore, significant energy uses (SEUs) can be identified.

\subsubsection{EnPI target}

Every year, ea ch organization's energy team calculates the overallenergy consumption based on theplanned production for the purpose of setting corporate EnPI targets. The submissions go through intensive reviews and analy sis from different levels of management to finally get approved by EMSC. 


\subsubsection{Obtain financial commitments}

At the corporate level, energy efficiency optimization has been included a s one of the capital proj ects reviews stages. This is to ensure all a pproved projects are energy efficient. At orga nizations levels, EnMS requirements and goals are major elements that a re considered during the business planning cycle reviews. Organizations must include the following energy efficiency plans during the business planning cycle review; energy improvement initiatives and projects to meet EnPIs targets, Energy coordinators and team development and training, energy campaign and conferences, and contractor a nd purchasing process.

\subsubsection{Knowledge sharing and recognition}

The EnMS requires oil companies to conducts energy a wareness programs to all employees including workshops, conferences and campaign corporate wide or small sca le within orga nization. These events encourage les sons lea rned, best practices development and benchmarking of energy perfomance internally or externally.

\subsubsection{Obtain Full Engagement From Organization}

Successful implementation of EnMS is a challenging milestone that requires highest level of commitments from themanagement of any concerned oil company. Energy should be considered a s one of significant operating cost parameters, and the one that should be a lways important to management and concerned stakeholders [22]. Therefore, these ex pectations should be part of a viewpoint to the EnMS. According to the IPIECA [4], the EnMS shall consist of customized steps to address each applicable business goals of concerned companies.

To win the management buy-in, the concerned management should be provided with a clear linking of all rela ted steps to defined business goals, e.g., health, safety, environment, costefficiency, relia bility and profitability. With a clear picture, it ca n promote the importance of EnMS to the highest level at par with other matured programs, e.g., SMS, EMS, TPM, and several other programs. Figure 2 illustrates links between expectations, steps of EnMS, and each business goal.

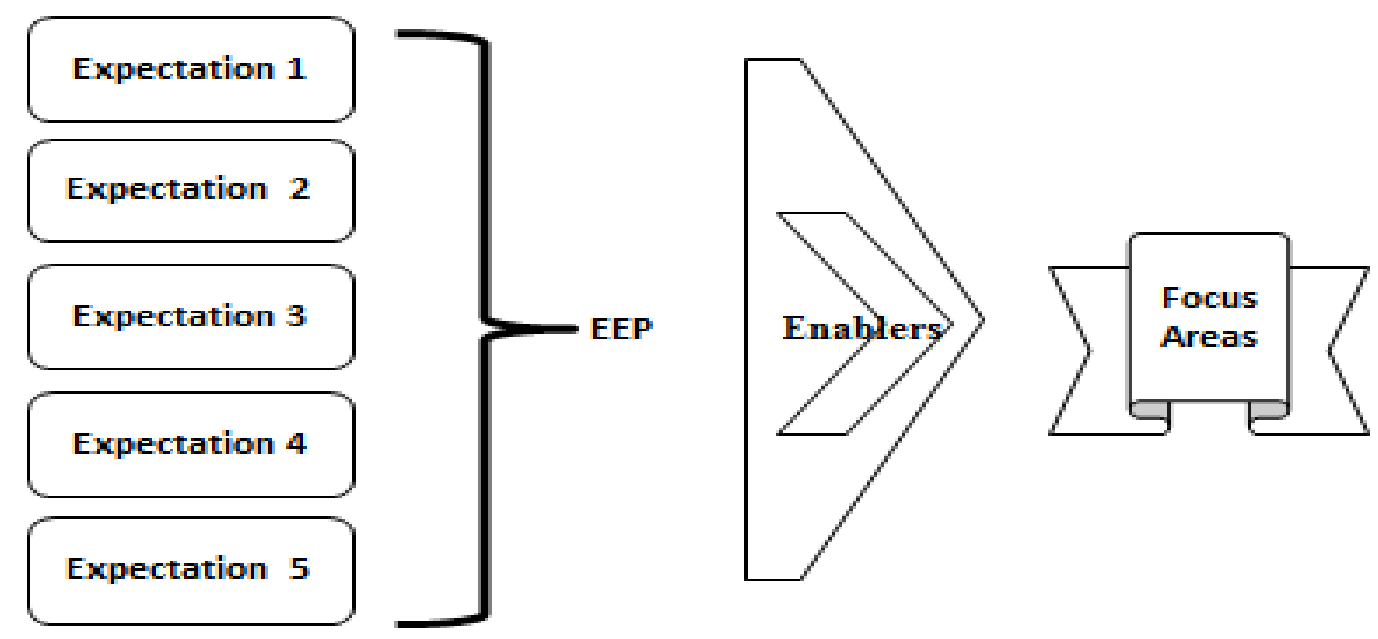

Figure 2 Linking between expectations, EnMS' steps and applicable business goals

The management of concerned oil companies should be convinced on tangible and intangible advantages for implementing EnMS. They shall be informed that the main benefit of the EnMS is to serve as an effective and sustainable process that can induce productivity. In addition, the EnMS pushes in enhancing environment performance by means of reducing GHG emission as well as natural resources intakes. Number of benefits can be realized with the embracing solid EnMS, wh ich focuses in minimizing energy consumption in each process unit, area, or activity.

The firmed commitment from top management is the key success of the program. Many measures that can trigger management focus. Such measures are summarized from the receiv ed feedback from surveys, as well as by referring to lessons learned from proven sources. The main one is to link to most of the business goals. In reality, focusing on energy conservation and efficiency 
efforts can tremendously reduce GHG footprint, minimize release of hazardous emissions, pollution, and many other HSE impacts. In addition, EnMS will drive for improvement in energy utilization, relia bility of services or products a s well a s c ost and profitability [13].

\subsubsection{Subscribe to Reputable And Latest Standards}

The United Nations Industrial Development Organization (UNIDO) has concluded that industries around the world need to implement an effective response to climate change [17]. In 2007, UNIDO requested ISO to develop an international energy management standard as preferred reference documents. Subsequently, a committee was established in 2008 to draft the dedicated energy management standards. EnMS (ISO 50001:2011) wa s officially a nnounced and published for global a doption in 2011 [18]. Since then, ISO 50001:2011 has become a major reference and has replaced number of energy management related standards such asBS EN 16001 (British Standard for Energy Management), Superior Energy Performance (SEP) from American Na tionalStandards Institute (ANSI), Energy Star from USA'Environment Protection Agency (EPA) and other rela ted energy efficiency practices [4]. In 2018, new revision of ISO 50001(ISO 50001, 2018) wa s released after incorporated feedbacks from implementers around the globe [5].

Strengthen EnMS governance by subscribing to reputable and latest international standards of ISO 5000:2018. Management should be informed that gaining an ISO 50001 certification is evident to demonstrate company commitment to fulfill Conference of the parties (COP) 21 [19] in reducing GHG generation and other environmental impacts as expected by stakeholders. Tapping to recent well-structure practices, such a s the latest international standards of ISO 5000:2018 is a well proven strategy measure to excel in energy performance.

EnMS' steps a re a ccordance to Deming' Plan-Do-Check-Act (PDCA) cycle [20]. A brief description of EnMS rela ted PDCA is listed perfollowings [4]:

Plan Establish policy, assign function and responsibilities, set objectives and targets, create a monitoring ca mpaign, and define energy pla ns.

Do Establish policy, assign function and responsibilities, set objectives and targets, create a monitoring campaign, and define energy plans.

Check Raise awareness, improve competency, and identify energy savings opportunities, as well a s efficiently operate identified significant energy uses (SEUs).

Act Conduct management review, recognize achievement, and gather feedback to enhance energy performance.

Simplified EnMS steps and its relationship between each EnMS element as per PDCA cycle is concluded and illustrated in Figure 3.

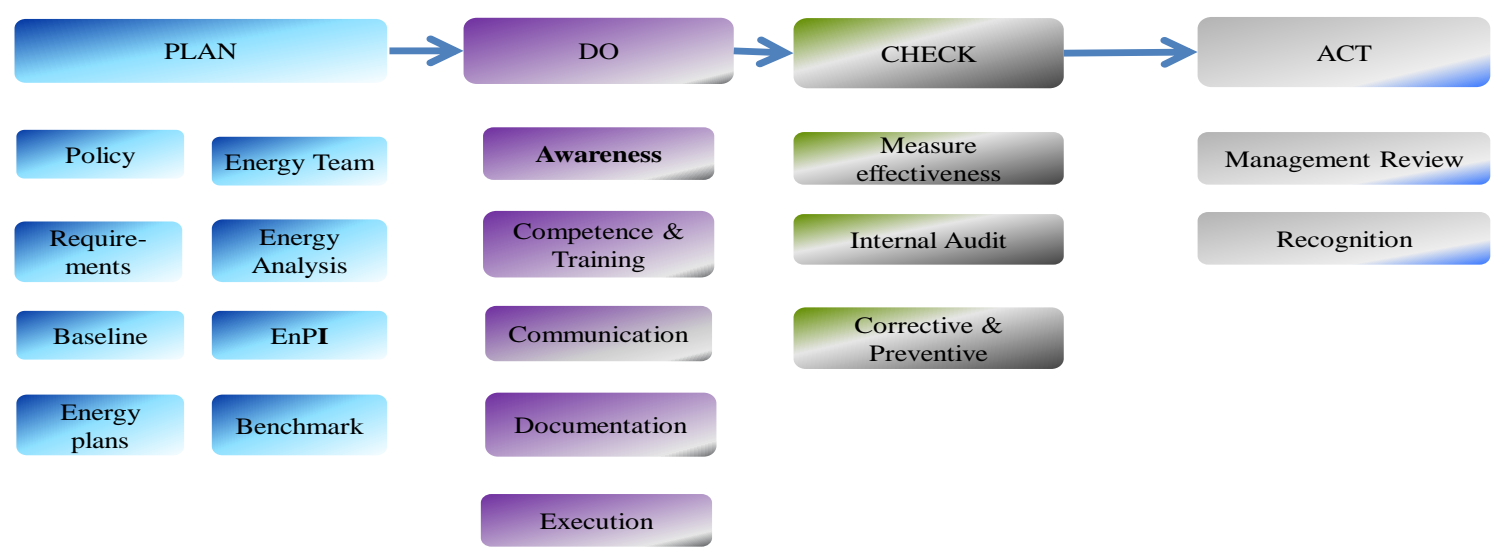

Figure 3 Simplified EnMS steps [4] 


\subsubsection{Ensure the EnMS Impels For Energy Savings}

Implementing the EnMS requires a solid effort and commitment from the concerned oil companies [4]. Therefore, the review shall be conducted to en sure the concerned companies can gain significant benefits by implementing the EnMS. The first action to be conducted prior engaging concerned oil companies is to check the applicability to EnMS a s a pre-requisite. It is very important to ensure that EnMS will benefit them, a nd will elimina te unnecessary allocation of resources. In additional, defining applicability of each company is important to ensure the EnMS is not overwhelmed. It will provide encouraging messages to the concerned entities for their contribution in achieving the specific goals.

Applicability to the EnMS requirements can be determined based on the defined requirement, such as consumption limits, as indicated by Table 3. Several countries such as Malaysia, Australia, and Singapore have issued a mandatory requirement on EnMS participation for certain types of industries, including refineries, petrochemicals, and other production facilities.

Upon meeting the threshold limit as defined by respective companies, the development of energy policy and other steps and sub-steps as required by its a dopted EnMS guidelines will follow. Subsequently, any applicable company shall p roceed to establish EnMS in accordance to the subscribed standards.

Table 3 Threshold limit for implementation of EnMS

\begin{tabular}{|c|c|}
\hline Country & Minimum annual energy consumption, GWhr* \\
\hline Australia & $139[21]$ \\
\hline Singapore & $15[22]$ \\
\hline Japan & 12 (or 3000 kiloliter of crude oil $\left.{ }^{* *}\right)[23]$ \\
\hline Malaysia & $6[24]$ \\
\hline ISO 50001:2018 & No limit***[5] \\
\hline \multicolumn{2}{|c|}{$*$ GWhr is a Gegawatt of power used continually for one hour. } \\
$* *$ HHV Crude oil (GJ/Kiloliter): 30 \\
N**Applies to companies that use energy and responsible for its cost and maintenance.
\end{tabular}

\subsubsection{Embed EnMS into Existing And Matured Management Programs}

The surveys in section 3.1 indicate that prior to a push for EnMS implementation in oil companies, strong efforts from all employees and respective contractors a re required. In most oil companies, EnMS is not in the priority list or even mentioned in business goals, particularly in na tional oil companies. To embed EnMS as part of a n aggressive management initiatives model is a preferred strategy, to drive for dra stic im provement progress. The model depends on specific company characteristics, such as political, socio-cultural, economic, technological, environmental, and legal a pplication [25].

As an outcome from the surveys (Section 3.1), it a ppears that EnMS is a required driving vehicle to ease supports from concerned company' entities. In this case, EnMS can be embedded as part of matured management initiatives models. A strong push through common management platforms is required, e.g., total quality management (TQM), opera tional excellence model (OEM), relia bility centered management (RCM), TPM or lean six sigma (LSS). This is a smart way to impelenergy efficiency application within the company.

One of the lea ding oil companies has successfully improved the implementation of EnMS under the umbrella of OEM [13]. It is a proven methodology that induces overall success to this company by saving significa nt a mounts of ene rgy and reduction in tones of GHG. Subsequently, the company realizes the other intangible benefits that enhance their performance such as gaining competitive advantage in improving their business performance and becoming a reference company. Adopting OEM driving platform will benefit the concerned oil companies by means of the following:

- Standardization and enhancement of major work processes across the company functions.

- Reduce time spend during development, implementation, performance monitoring and go verning the EnMS.

- Capture and dissemination of tacit knowledge retained by a few subject matter ex perts.

- Clarifica tion of accountabilities and responsibilities to function within any concerned company.

- Enhancement of asset integrity and relia bility techniques and processes.

- Engage full attention to all required expectations, processes, and business goals.

- Optimize resources through consolid ate compliance assessment on other matured programs. 


\subsubsection{Introduce a Comprehensive Framework Template}

The framework template includes all relevant references as well a s examples and be tested for practicality. It has to be simple and provide a clear description that can attract any a pplicable oil company to deploy EnMS ef fectively. EnMS implementation requires a strong commitment from the entire company. With allocation of adequate resources such as man-power, operating and investment cost to drive for improvement in energy performance.

The purpose of comprehensive framework template is to a ssist concerned oil companies to ease the time and effort in deploying and implementing an EnMS. Main contents of the proposed framework are a simplified EnMS steps and sub -steps in reference to ISO 50001:2018. The framework is embedded with structured deployment tips that can drastically improve the implementation pace of EnMS. Subsequently, by deploying a customized EnMS, it will drive the concerned companies towards integrating the relevant steps or sub-steps into its existing programs. Therefore, it will benefit each company in resource a lloca tion, short cutting the introduction process and focuses on criticality.

With the introduction of a comprehensive EnMS framework template which includes checklists, typical EnPIs, plans and many other critical steps and sub-steps, it induces EnMS as one of excellent programs to be expedited. The established EnMS shall consist of necessary clauses to a ddress identified business goals and to evident the criticality of it. The EnMS fra mework template provides a structured approach to achieve and sustain leading performance in their specific areas, while striving on effectiveness and profitability. Following a framework template is something that companies must attempt to adopt and start with. The truly successfulones are those who implement a comprehensive EnMS framework template effectively.

\subsubsection{Provide Energy Improvement Guidelines Template}

Most oil and gas production facilities are technology-pervasive industries. These types of industries require high capital investment with highly diverse concerns including a ssociated business risks, HSE related impacts, sta keholders, and sociopolitics of the hosting countries. The benefit of deploying new technologies a nd innovations shall ba lance the potential downside of a failure [26]. Inclusion of energy improvement guidelines with focusing on self-help and quick fix initiatives can partially reduce the gaps, and then strengthen it to pa ve the way towards improving companies' profitability.

Energy sa vings can be realized by focusing on initia tives, e.g., operational improvement, quick fix or an initiative that req uires high CAPEX. Also having an energy improvement team (EIT) is essential to explore energy savings opportunities. The team must ex ert rigorous efforts, including technical competency on energy rela ted subjects, securing support from management, and establish reference guidelines. Ideally, the guidelines should be established based on energy improvement know-how, bestpractices, lessons learned and well-known litera ture from internal and ex ternal sources, so that all significa nt energy efficiency concepts will not be missed out.

Examples of widely a ccepted energy sa ving initiatives are listed in Table 4 . The implementation measures are preliminary, and further confirmations are required to be quantified. In fact, each identified initiative shall be evaluated promptly through the following subjectitems:

i. Technical evaluation to ensure each proposed initiative is technically acceptable.

ii. Operationalevaluation to check for implementation practicality on each proposed initiative.

iii. Simple risk analysis such as strength, weakness, opportunity and threat.

iv. Incentives: financial, GHG reduction and carbon trading program.

v. Process safety management (PSM) review such as management of change (MOC), hazard and operability study (HAZOP) review and other specific requirements for each a pplicable company.

vi. Initiativeexecution plan.

vii. Decision making and path forward plan.

v. Method of verifying results. 
Table 4 List of typical energy sa ving opportunities [26]

\begin{tabular}{|c|c|c|}
\hline No & Area of opportunity & Approach \\
\hline 1 & $\begin{array}{l}\text { Steam loss due to malfunction steam } \\
\text { traps and pipe leaks }\end{array}$ & $\begin{array}{l}\text { Improve steam traps reliability, revisit design, and replace with } \\
\text { more efficient units and increase inspection frequency. }\end{array}$ \\
\hline 2 & $\begin{array}{l}\text { High furnace flue gas excess oxygen } \\
\text { levels }\end{array}$ & $\begin{array}{l}\text { Reduce excess oxygen level to the optimum point and review } \\
\text { excess oxygen control scheme. }\end{array}$ \\
\hline 3 & Burner combustion issues & $\begin{array}{l}\text { Check burner condition frequently and make adjustment as } \\
\text { needed. }\end{array}$ \\
\hline 4 & Steam header pressure control & $\begin{array}{l}\text { Reduce steam pressure to the optimum limits acceptable to } \\
\text { process. Plant test may be required. }\end{array}$ \\
\hline 5 & $\begin{array}{l}\text { Cooling water system - high water } \\
\text { circulation and fans control }\end{array}$ & $\begin{array}{l}\text { Reduce number of pumps in operation and introduce fans } \\
\text { operating strategy. Plant test is required. }\end{array}$ \\
\hline 6 & High plant water usage & $\begin{array}{c}\text { Reduce overall plant water usage, cooling water improvement, } \\
\text { piping reliability and water saving awareness events. }\end{array}$ \\
\hline 7 & Poor motor efficiency & Revise maintenance procedure in replacing and procure motors. \\
\hline 8 & High steam deaerator vents & $\begin{array}{l}\text { Reduce deaerator working pressure to minimize steam used for } \\
\text { scrubbing. Plant test is required. }\end{array}$ \\
\hline
\end{tabular}

Ultimately, the energy improvement guidelines template should provide brief description of typical energy improvement initiatives as per the following subjects [26]:

- Introduction of scope and coverage of theimprovement guidelines. It shall include expectations for energy coordinators, members of its energy team as well as other energy critical positions.

- Description of specific procedure based on company' know-how and external best practices, lessons leamed and well-known literatures, but not limited to the following scope:

- Energy programs provide mechanism for continuous improvement in energy performance e.g., planning, training, communication, accoun tability, monitoring, reporting, feedback and recognition.

- Performance monitoring a pproach to tra ck progress of energy optimization program.

- Mea suring and metering a re critical to en sure successful energy performance monitoring efforts.

- Heat exchanger im provement program.

- Furnaces/Fired boiler improvement program.

- Air preheaters' improvement program.

- Waste-heat recovery unit improvement program.

- Steam systems improvement program.

- Electrical systems improvement program.

- Flare systems im provement program.

- Vacuum systems improvement program.

- Rotating equipment improvement program.

- Miscellaneous heating/cooling systems and insulation.

- Effluent treatment plant.

\subsubsection{Define Performance Monitoring Program}

The first task for continual improvement in energy performance is to define EnPIs. A right selection of EnPIs will enhance tracking of the overall implementation progress against defined EnMS expectations and other desired performancetargets [27]. Moreover, dedicated actions can be taken to correct them as defined duration. EnPIs will ensure common objectives of EnMS (e.g., increa se reputation, improve energy intensity, reduce cost and GHG emissions) a re met [28]. 
The ultimate a pproach is to a pply la gging and leading EnPIs. The la gging EnPIs are based on actual operational data that reflect the as-is situa tion of energy performance, and a re commonly a pplied by oil companies [4]. A basic measure of la gging EnPI is a lso known a snergy Intensity (EI) or Energy Utilization Index (EUI) in industry and building respectively. EI is a measure of the energy required in generating a unit of products [29]. Meanwhile, EUI is a measured value of the amount of energy annually used for cooling or heating a building or facility per area of conditioned space [16].

Meanwhile, overall progress in driving for continuous improvement in the energy performance can be tracked through the lea ding EnPI [30]. It appears that the leading EnPI is a preferred tracking tool to monitor the progress of continuous improvement in overall energy performance, tracking performance scorecard, and reporting results of EnMS implementation [32]. Leading EnPI can also be applied to monitor the progress a gainst the implementation objectives of EnMS in which companies are deployed [33].

As to summarize, the proposed leading EnPI indicators can be a pplied to a ssist concerned companies in tra cking their lea ding performance, a s per the following [30]:

- Implementation status of energy improvement initia tives.

- Energy performancetrends such a energy efficiency by product, process unit and major equipment

- Energy objectives a nd targets the status of a chievement.

- Effectiveness of operational and maintenance activities to enhance energy efficiency.

- Level of awareness among the companies' management and employees.

- Level of competency of energy rela ted personnel.

- InternalEnMS a ssessment performance.

- Overall implementation of EnMS.

\subsection{Case Study For Deploying EnMS}

In a case study [15], Saudi Arabian Company (SAC) has successfully implemented the EnMS by implementing the systematic a pproach as described in Section 3.2. It can be considered as major a chievement for worldwide EnMS implementation as SAC is large corporation involves six main disciplines. SAC disciplinesa re segregated according to specific tasks a nd location as per Table 5 .

Table 5 Main disciplines' description

\begin{tabular}{|c|l|}
\hline Disciplines & \multicolumn{1}{c|}{ Description } \\
\hline 1 & $\begin{array}{l}\text { Main function is to treat and process the raw gases to meet the power plants and downstream requirements. This division } \\
\text { consists of six gas treatment facilities. }\end{array}$ \\
\hline 2 and 3 & $\begin{array}{l}\text { Main function of these two divisions is to provide oil, gas and water separation from raw crude and gas wells. These two } \\
\text { divisions are separated by demography. Both of these divisions consist of five production facilities. }\end{array}$ \\
\hline 4 & This is a downstream division that consists of six refinery and condensate splitters facilities. \\
\hline 5 & $\begin{array}{l}\text { This division is dedicated to provide transportation of treated crude and gas from oil and gas storage facilities to users and } \\
\text { customers. This division consists of six facilities. }\end{array}$ \\
\hline 6 & Marines, transportation and maintenance. \\
\hline
\end{tabular}

SAC has initiated the EnMS at corporate level since year 2005, even before the establishment of internationally recognized ISO 50001 for EnMS standard in mid of 2011 [18]. In 2012, over 50 of SAC applicable organizations were requested to embrace each element of the established EnMS guidelines. The major goals for the request include becoming more energy efficient, energy responsible, and to be able to demonstrate this responsibility to stakeholders, the government, a nd the public. The ma in reference for SAC' EnMS is the one published by ISO Standards (ISO 50001:2011) [18].

During the initial stage of EnMS implementations, delays can occur due to a lack of commitment or even rejection from respective parties. Some company organizations may not understand how to apply EnMS. These delays can becompounded by a lack of support from top management, limited resources, and geo-political structure.

Mitiga tion of these issues in rea lizing the full benefits of implementing EnMS was investigated. After conducting a number of surveys, reviews, a nd brainstorming sessions, it was concluded with the following im plementation recovery strategies:

- Embedded EnMS under OEM umbrella.

- Confirmed a pplicability of the EnMS to impelenergy sa ving.

- Introduced a comprehensive framework template to ease deployment of EnMS for new identified organizations. 
- Concluded performance monitoring program. Both lagging and leading EnMS have to be included in the monitoring program.

- Published energy improvementguidelines.

The a pplicability of SAC organization s to EnMS was determined in Table 6. As of 2017, there were more than 50 organizations that had successfully confirmed their a pplicability, based on this checklist. It provided a solid justification for these organizations to deploy the EnMS prior to earning cost savings. In addition, it could sustain their fin ancial performance by reducing opera ting cost, and minimizing expenses associated with environmental-related activities. Ultimately, these organizations started to link EnMS to certain business goals, in particular "efficiency" and "environment".

Further enhancement took place in 2013, as SAC introduced the OEM to strengthen its business portfolio, and the EnMS was concluded as one of the SAC' critica l programs. Deployment of EnMS as part of OEM is an effective strategy to promote and mandate full EnMS implementation company-wide. Part of the implementation methodology is to customize EnMS by incorporating selected expectations from OEM. In addition, adoption of EnMS into OEM will enhance management commitment and provide clear links to SAC relevant business goals.

As part of EnMS deployment initiatives, the framework template wa sintroduced to the concerned organizations of SAC in late 2015. SAC hasfully relied on this template as a main reference to deploy the EnMS since it was considered new to the company. The fra mework template is a important quick reference of EnMS to ease deployment and later to push for full implementation of EnMS by applicable organizations. The framework template includes all relevant steps, sub-steps, activities and guided approaches for a successful implementation of the EnMS. The comprehensive EnMS framework template will allow any concerned organization to quickly establish and therefore integrateEnMS into their management practices, including fine-tuning production processes and improving the energy efficiency of their systems.

Table 6 Threshold limit for implementation of EnMS

\begin{tabular}{|c|l|l|l|}
\hline No & \multicolumn{1}{|c|}{ Questionnaires } & Yes / No & Remark \\
\hline 1 & $\begin{array}{l}\text { Does your organization consume electricity or fuel or any other form } \\
\text { of energy above 21,000 mmBTU/year Note-1? }\end{array}$ & & \\
\hline 2 & $\begin{array}{l}\text { Does your organization involve in energy }\left(\text { power }^{\text {Note-2 }} \text { ) generation for }\right. \\
\text { internal or external use? }\end{array}$ & & \\
\hline 3 & $\begin{array}{l}\text { Does your organization involve in the production of energy } \\
\text { resources }\end{array}$ & & \\
\hline 4 & $\begin{array}{l}\text { Dote-3 ? } \\
\text { authority } \text { Note-4? }\end{array}$ & & \\
\hline
\end{tabular}

Definitions;

\section{Note 1: Approximate $6 \mathrm{GWhr} /$ year}

Note 2: Electricity

Note 3: Oil and gas

Note 4: Statutory requirement

The most convincing factor of successful EnMS implementation in the eyes of management is the cost savings ga ined. In this purpose, the introduced energy improvement guidelines are to describe a methodology of quick energy assessment approaches. Therefore, energy improvement can be conducted faster and effectively. Quick energy assessment methodology is a step-bystep manner that includes simple models for data representation and checklists for identifying and evaluating energy saving initiatives. The guidelines are intended to be a main reference to energy coordinators, energy engineers, specialists or other concerned energy practitioners responsible for efficient operation of their organizations.

In tra cking the overall orga nization energy performance, lagging EnPI concept of energy consumed in giga joule (GJ) over the final product in metric ton is used as a basis for EnPI calculation. Due to confidentially, these tracking trends will not be revealed. As an example, EnPI for Downstream facility of Purified Terephthalic Acid (PTA) is shown in Figure 4. The target line is marked on the chart to easily indicate its energy performance. 


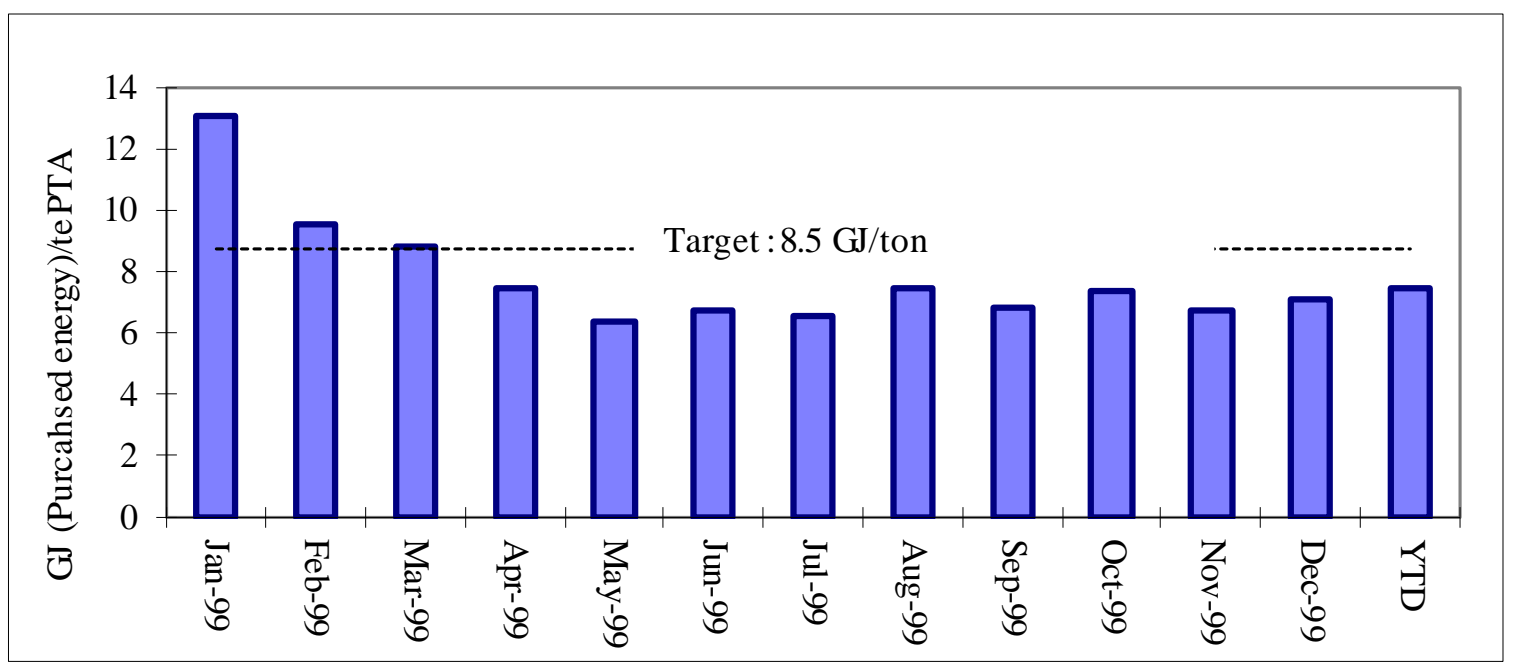

Figure 4 EnPI for one PTA manufacturing facility [31]

A leading EnPI has been successfully implemented to track SAC organizations progress towards excellence in energy performance. At defined interval, each of the concerned orga nization conducts a comprehensive self -assessment, ba sed on customized questionnaires, to gauge the progress of its EnMS implementation against EnMS critical steps, e.g., Plan is to define energy plans, Implementation is to conduct im provements, Check is to track energy plans implementation, and EnPIs, Act is to conduct managementreviews. The customized EnPI was based on an a llocated weight for each of the major EnMS stages as per the Deming quality cycle of PDCA, where a certain weight to reflect the current needs of each organization was given. The maximum weight of $100 \%$ will be a lloca ted to an organization that fully meets all a greed expectations. The allocation for PDCA in this ca se study was an equal weight of $25 \%$ [30].

In conclusion, embedded deployment strategies have drastically improved the implementation pace of EnMS. As indicated in Figure 5, within less than four years since it wa s initiated, the progress of company-wide EnMS implementations has boosted up to $89 \%$ towards meeting the minimum requirement of ISO 50001. It was based on the leading EnPI measures, as discussed in the previous paragraph. Many of the SAC' organizations have scored full marks on their EnMS self-assessment. The systematic approach from well-structured methodology has resulted in a significant energy savings and a tremendous reduction of GHGemissions.

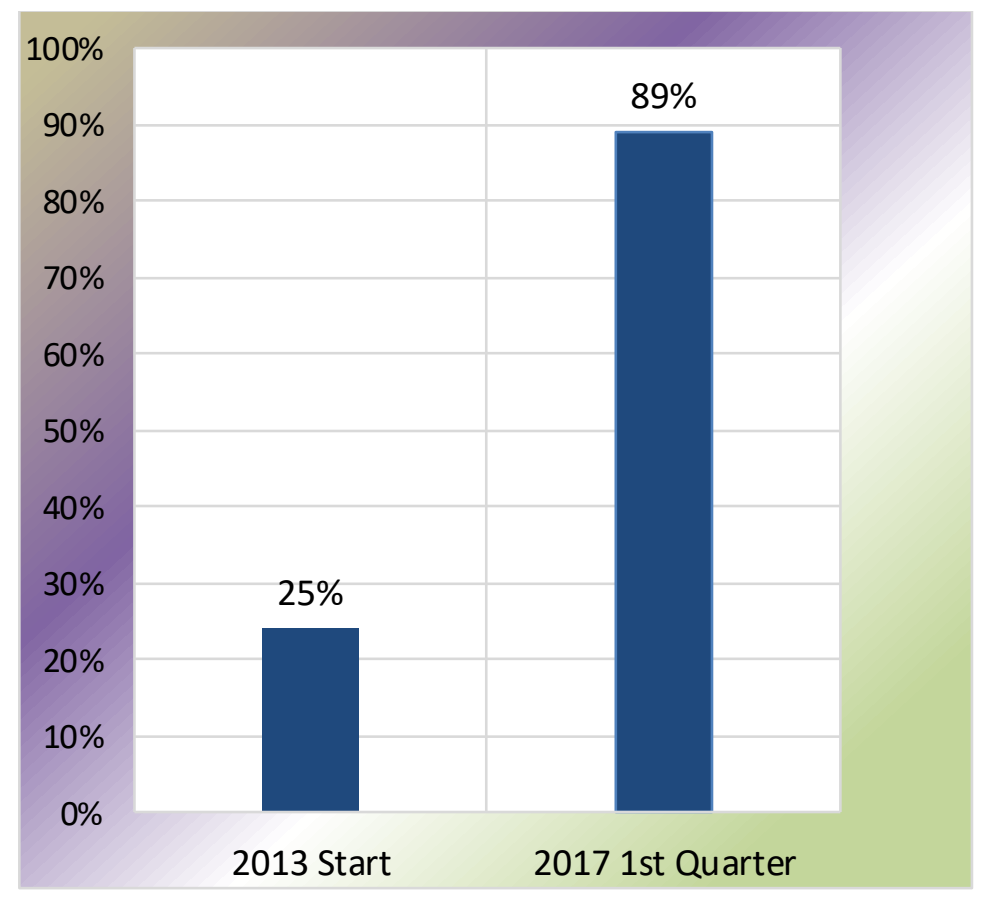

Figure 5 Company EnMS implementation progress 


\subsection{CONCLUSION}

It is a need for systematic strategies prior to realize for sustainable EnMS implementation in concerned oil companies. Main sustainable measures can be realized by full implementation of EnMS, which include reduction in OPEX from energy improvement, minimization of environment impacts through well-structured energy resources management, and enhancement of the company image in the eyes of stakeholders, by engaging international recognizedEnMS.

The paper listed seven strategies that can be considered to ease EnMS deployment and implementation by any concerned oil company. Such strategies e.g., engage top management commitment, subscribe to reputable and la test standards, ensure the EnMS impels for energy savings, embed EnMS into existing and matured management programs, introduce a comprehensive fra mework template, provide an energy improvement guideline, and define the performance monitoring campaign.

These strategies, has a nd been successful a pplied by many organizations in one leading oil company. It is evident from the ca se study that the proposed strategies such as imbedded EnMS a s one of the OEM critical processes, applied comprehensive fra mework template as a deployment/ implementation starter kit, and tracking energy improvement a re managed to engage strong commitments from all level of employees. The real benefits and the opportunities for improvement will be captured during the actual deployment of EnMS. One of the major benefits is to ea se the adaptation of the strategies, and ultimately d rive for steady incremental improvements of energy performance. These strategies a re easily implemented, without the need for neither a major a llocation of resources nor a lengthy deployment time frame.

\subsection{Limitation}

Although a significant amount of works has been done to conclude the paper, several enhancement efforts still persist. Such limitations include resource constraint in term of references, software availability, a nd detailed energy improvement list.

\subsection{Recommendation}

The proposed a pproach is still new despite of some organization s have been conserving energy program since decades before. There are many business opportunities that can be explored such as EnMS deployment support, starter kit, framework template, dedicated training programs as well a s consultancy services,

\section{Acknowledgement}

The authors would like to express their sincere gratitude to one anonymous national oil company for providing access to the venue and facilities during the case study.

\section{References}

[1] Cottier, T. and Delimiters P. 2011. The Prospects of International Trade Regulation from Fragmentation to Coherences. (1st ed.). UK. Cambridge University Press.

[2] Worell et a1. 2006. Energy Efficiency Improvement in the Petroleum Refining Industry. Advisory Committee on Energy Efficiency (ACEE) Summer Study Energy on Efficiency in Industry. International Electrotechnical Commission (IEC), Geneva, Switzerland.

[3] SEEP. 2018. Building sector. Saudi Energy Efficiency publication. March 13, 2018.

[4] IPIECA. 2013a. Guidelines for implementing ISO 50001 Energy Management System in Oil and Gas Industry. The global oil and gas association for environment and social issues. Climate Change. International Association of Oil and Gas Producers, London, UK

[5] ISO 50001. 2018. Energy Management Systems - Requirements with guidance for use. International Standards Organization. Switzerland..

[6] DNV.GL 2015. Saving Energy Today for brighter tomorrow. View Point Report. May 2015. Norway.

[7] Equinor. 2016. Equinor warns that the energy transition is “too slow'. Near Surface Geoscience. First Break. 36(3), August 2018 : 31.

[8] Dipaola, A. 2017. Saudis Kick Off \$50 Billion Renewable Energy Plan to Cut Oil Use. Bloomberg, (20 Feb 2017). 
[9] Luca, C. 2018. Regain Trust by Aligning with Society's Need. Journal of Petroleum Technology. 70 (6): 14.

[10] IPIECA. 2013b. Saving Energy in the oil and gas industry. The global oil and gas association for environment and social issues. Climate Change. International Association of Oil and Gas Producers, London, UK

[11] Kaplan, R. and Norton, D. 2001. Scorecard companies thrive in the new business environment. The Strategy-Focused Organization. How balance. (1st Ed). USA. Harvard Business School Press.

[12] Arab Forum. 2013. Environment and Development Executive Report Summary Recommendations. Arab Environment 6 Sustainable Energy Prospect, Challenges, Opportunities. Beirut, Lebanon. $1 \& 9$.

[13] Hashim et al. 2018a. Advancing Energy Performance in Oil and Gas Industry through Systematic Implementation of Energy Efficiency Programs by applying an Operational Excellence Model. Journal of Energy and Safety Technology. 1(2): 51- 59. Penerbit UTM Press

[14] Galisky et al. 2005. Energy Improvement in the Petroleum Refining Industry. 2005 Summer Study for Energy Efficiency in Industry. Associate Energy Engineers. USA

[15] Altuwayrish, B. 2016. Site Energy Management Systems (EnMS) Development and Implementation in Saudi Aramco. Proceedings of the 10th Middle East Refining and Petrochemicals Conference. September 26-29, 2016. Bahrain 17

[16] Turner, C.W. 2001. Energy Management Handbook. (4th Ed.). USA. The Fairmont Press.

[17] UNIDO 2010. Global Industrial Energy Efficiency Benchmarking. An Energy Policy Tool Working Paper, Nov2010. United Nations Industrial Development Organization, Vienna, Austria. xi - 3.

[18] ISO 50001. 2011. Energy Management Systems - Requirements with guidance for use. International Standards Organization. Switzerland.

[19] Worland, J. 2015. What to Know About the Historic 'Paris Agreement' on Climate Change. Time (2015, Dec 12).

[20] Pyzdek, T. and Keller, P. 2013. The handbook for quality management. Complete Guide to Operational Excellence. (2nd Ed.). USA. McGraw Hill.

[21] Australia Government. 2013. Energy Savings Measurement Guide. How to estimate, measure, evaluate and track energy efficiency opportunities. Australia' Department of Resources, Energy and Tourism Version 2. Australia.

[22] National Environment Agency. 2013. Singapore's Mandatory Energy Management Requirement. Energy Conservation Act (ECA). Singapore.

[23] Japanese Government. 2013. Cabinet Decision on the Bill to Partially Amend the Act on the Rational Use of Energy (Energy Conservation Act). Japanese Minister of Economy, Trade and Industry Press Release.

[24] EMEER. 2008. Efficient Management of Electrical Energy Regulations 2008. Electrical Supply Act (P.U. (A) 444).

[25] Mullins, L.J. 2005. Management and Organizational Behavior. (7th Ed.). UK. Prentice Hall.

[26] Hashim et al. 2018b. Identify Energy Saving Opportunities from Operational "Self-Help" and "Quick Fix" Optimization Approaches. Journal of Energy and Safety Technology. 1(2): 41- 49. Penerbit UTM Press.

[27] Lindberg et a1. 2015. Key Performance Indicators Improve Industrial Performance. The 7th International Conference on Applied Energy - ICA2015 Proceeding. Energy Procedia. Elsevier.

[28] Nuaim, A,S. 2019, 'One year of sustainability is not enough'. Journal of Petroleum Technology.71(8): 10.

[29] Solomon. 2013a. Fuels and Refinery Performance Analysis. Energy Intensity Index Analysis Methodology. Salomon Associates. 1.

[30] Hashim et al. 2019. Leading Energy Performance Indicator. Academy of Science Malaysia Journal. 12 (2019): 10-16.

[31] Hashim, M. K. 2004. Water Management Study for BP Chemicals (M) Sdn Bhd. Master of Science. Technology University of Malaysia, Skudai.

[32] Marcus, A. 2011. ICT and Eco-sustainability Working Group for McKinsey and Company. World Economic Forum. Davos, Switzerland. 29.

[33] Estes, J.M. 2009. Smart Green. How to implement sustainable business practices in any industry - and make money. (1st Ed). USA. J. Wiley \& Sons, Inc. 